\title{
Analisis Pengembangan Website Menggunakan Metode Kano (Studi Kasus: BRSPDF Budi Perkasa Palembang)
}

\author{
Mutiara Jesica $^{\text {() }}$, Gusmelia Testiana ${ }^{2)}$, Sri Rahayu ${ }^{3)}$ \\ ${ }^{12) 3)}$ Fakultas Sains dan Teknologi, Program Studi Sistem Informasi, Universitas Islam Negeri Raden Fatah \\ Jl.Prof.K.H.Zainal Abidin Fikri KM.3,5, Palembang

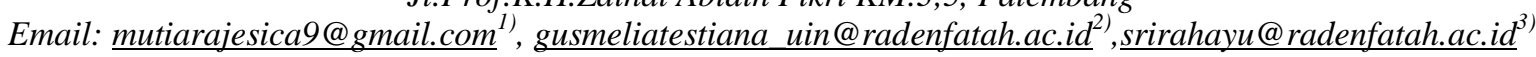

\begin{abstract}
This research was conducted with the aim to find out the categories of attributes on the website of the Social Rehabilitation Center of Persons with Physical Disabilities Budi Perkasa Palembang so that it can be known the steps to improve or add content for development on the website, to determine the level of satisfaction and the level of user disappointment with the website, and to know the priority of applying content for development on the website later using the Kano method. After conducting interviews, Customer Requirements were obtained in the form of Content Home Improvements, Content Profiles Improvement, Online Registration Content Additions, Photo Gallery Content Improvements and Guest Book Content Additions. The results of this study found that the priority of implementing the first content is the addition of Online Registration content in the Must-Be category (with a satisfaction level of 0.375 and a level of disappointment -0.50), followed by improvements to the content of the Home (with a satisfaction level of 0.625 and a level of disappointment -0.625) and improvements to the Photo Gallery content (with a satisfaction level of 0.50 and a level of disappointment of $-0,625)$ in the One Dimensional category, and finally the Improvement of the Profile content (with a level of satisfaction of 0.50 and a level of disappointment of -0.375) and the addition of the Guest Book content (with a satisfaction level of 0.50 and a level of disappointment -0.125) which is in the Attractive category.
\end{abstract}

Keywords : Content, Kano Method, Social Rehabilitation Center for Persons with, Physical Disabilities Budi Perkasa Palembang

\begin{abstract}
ABSTRAK
Penelitian ini dilakukan dengan tujuan untuk mengetahui kategori dari atribut atribut dalam website Balai Rehabilitasi Sosial Penyandang Disabilitas Fisik Budi Perkasa Palembang sehingga dapat diketahui langkah-langkah perbaikan atau penambahan content untuk pengembangan pada website, untuk mengetahui tingkat kepuasan dan tingkat kekecewaan pengguna terhadap website, dan untuk mengetahui prioritas penerapan content untuk pengembangan pada website nantinya dengan menggunakan metode Kano. Setelah dilakukan wawancara didapatkan Customer Requirement berupa Perbaikan Content Home, Perbaikan Content Profil, Penambahan Content Pendaftaran Online, Perbaikan Content Galeri Foto dan Penambahan Content Buku Tamu. Hasil dari penelitian ini didapatkan prioritas penerapan content yang pertama adalah penambahan content Pendaftaran Online yang masuk dalam kategori Must-Be (dengan tingkat kepuasan 0,375 dan tingkat kekecewaan -0,50) disusul dengan perbaikan content Home (dengan tingkat kepuasan 0,625 dan tingkat kekecewaan -0,625) dan perbaikan content Galeri Foto (dengan tingkat kepuasan 0,50 dan tingkat kekecewaan -0,625) yang berada pada kategori One Dimensional, dan yang terakhir Perbaikan content Profil (dengan tingkat kepuasan 0,50 dan tingkat kekecewaan -0,375) dan penambahan content Buku Tamu (dengan tingkat kepuasan 0,50 dan tingkat kekecewaan -0,125) yang berada pada kategori Attractive..
\end{abstract}

Kata kunci: Content, Metode Kano, Balai Rehabilitasi Sosial Penyandang, Disabilitas Fisik Budi Perkasa Palembang 


\section{Pendahuluan}

Perkembangan ilmu pengetahuan dan teknologi pada masa globalisasi ini dirasakan telah semakin pesat, dan memungkinkan kita mendapatkan informasi secara cepat, tepat dan efisien serta mempunyai manfaat yang sangat besar. Semua ini dikarenakan hasil dari pemikiran-pemikiran manusia yang semakin maju, hal ini ditunjukkan dengan banyaknya penerapan sistem informasi pada lembaga, perusahaan ataupun instansi lainnya.

Balai Rehabilitasi Sosial Penyandang Disabilitas Fisik (BRSPDF) Budi Perkasa Palembang saat ini telah menerapkan sistem informasi berupa website. Website ini dimaksudkan untuk membuat pegawai mudah untuk mengakses informasi secara online yang dapat dilakukan dimana saja dan kapan saja. Website BRSPDF Budi Perkasa Palembangsudah ada sejak tahun 2009. Website BRSPDF Budi Perkasa Palembang sudah berisi informasi-informasi mengenai kegiatan, agenda dan berita pada balai rehabilitasi, profil, visi serta misi balai rehabilitasi hingga link-link yang berkaitan dengan balai rehabilitasi. Oleh karena itu pihak pengurus BRSPDF Budi Perkasa Palembang sangat menginginkan analisis pengembangan berupa penambahan atau perbaikan content yang dibutuhkan pada website.

Akan tetapi tim pengembang ingin terlebih dahulu mengetahui content apa saja yang diperlukan pengguna dan content apa yang menjadi prioritas yang paling diminati oleh pengguna berdasarkan tingkat kepuasan pengguna jika content di terapkan. Serta mengetahui tingkat kekecewaan pengguna jika content tidak diterapkan. Untuk itu sebelum pengembangan diterapkan ke dalam website maka terlebih dahulu dilakukan analisis agar hasil pengembangan website nantinya sesuai dengan harapan pengguna.

Dengan adanya penelitian di Balai Rehabilitasi Sosial Penyandang Disabilitas Fisik (BRSPDF) Budi Perkasa Palembang, analisis pengembangan website dilakukanmenggunakan metode Kano yaitu metode yang bertujuan untuk mengkategorikan atribut-atribut dari produk maupun jasa berdasarkan seberapa baik produk tersebut mampu memuaskan kebutuhan pengguna. Kategori-kategori layanan dibedakan menjadi 6 yaitu, kategori Must Be, kategori One Dimensional, kategori Attractive, kategori Indefferent, kategori Reverse dan kategori Questionable. Metode ini mempertimbangkan penting atau tidaknya suatu ide atau permintaan pengguna (atribut) yang ada serta dapat mempertimbangkan besar kecilnya kebermanfaatan suatu ide atau permintaan (atribut) baru untuk diterapkan. Untuk itu metode kano adalah solusi yang tepat untuk digunakan sebagai metode analisis pengembangan website.

Berdasarkanpembahasandi atasmaka penulistertarikuntukmengangkat skripsi dengan judul. "Analisis Pengembangan Website Menggunakan Metode Kano (Studi Kasus: Balai Rehabilitasi Sosial Penyandang Disabilitas Fisik Budi Perkasa Palembang)".

\section{A. Metode Penelitian}

Metode Penelitian yang digunakan dalam penelitian ini adalah penelitian deskriptif kuantitatif. Penelitian deskriptif kuantitatif adalah penelitian yang mendeskripsikan suatu gejala, peristiwa, kejadian yang terjadi saat ini (Muri Yusuf, 2017:62). Pada penelitian ini penulis menggunakan analisis data statistik deskriptif. Statistik deskriptif dilakukan dengan tujuan mendeskripsikan keadaan dan hasil penelitian tanpa bermaksud membuat kesimpulan yang berlaku untuk umum dan generalisasinya.

\section{B. Kano}

Menurut Walden (1993) Metode kano dikembangkan oleh Noriaki Kano. Metode Kano adalah metode yang bertujuan mengkategorikan atribut-atribut produk maupun jasa berdasarkan seberapa baik produk atau jasa tersebut mampu memuaskan pengguna.

Metode Kano melakukan evaluasi terhadap atribut produk didasarkan pada respon dari pelangan. Respon pengguna terhadap kebutuhan konsumen (atribut produk) dibagi menjadi 6 kategori dan dapat dilihat pada Tabel 1, yaitu:

Tabel 1. Evaluasi Metode Kano

\begin{tabular}{|c|c|c|c|c|c|c|}
\hline \multicolumn{7}{|c|}{ Kano Evaluation Table } \\
\hline \multirow{2}{*}{\multicolumn{2}{|c|}{$\begin{array}{l}\text { Customer } \\
\text { Requirements } \rightarrow\end{array}$}} & \multicolumn{5}{|c|}{ Dysfunctional } \\
\hline & & $\begin{array}{c}1 . \\
\text { like }\end{array}$ & $\begin{array}{c}2 . \\
\text { Imust-be } \\
\end{array}$ & $\begin{array}{c}3 . \\
\text { neutral }\end{array}$ & $\begin{array}{c}4 . \\
\text { ylive with }\end{array}$ & $\begin{array}{c}5 . \\
\text { dislike } \\
\end{array}$ \\
\hline \multirow{5}{*}{$\begin{array}{l}\text { Func- } \\
\text { tional }\end{array}$} & 1. like & $\mathrm{Q}$ & $\mathrm{A}$ & $\mathrm{A}$ & $\mathrm{A}$ & $\mathrm{O}$ \\
\hline & 2. must-be & $\mathrm{R}$ & I & $\mathrm{I}$ & I & $\mathrm{M}$ \\
\hline & 3. neutral & $\mathrm{R}$ & I & I & I & M \\
\hline & 4. live with & $\mathrm{R}$ & $\mathrm{I}$ & I & $\mathrm{I}$ & $\mathrm{M}$ \\
\hline & 5. dislike & $\mathrm{R}$ & $\mathrm{R}$ & $\mathrm{R}$ & $\mathrm{R}$ & Q \\
\hline
\end{tabular}

1. Attractive (A). Attractive menunjukkan bahwa kepuasan pengguna meningkat apabila kinerja produk meningkat, namun kepuasan pengguna tidak akan menurun jika kinerja atribut produk tersebut tidak meningkat.

2. Must-be (M). Must-be menunjukkan bahwa jika atribut tersebut ada pada produk, kepuasan pengguna biasa-biasa saja. Namun jika atribut ini tidak ada pada produk, maka kepuasan pengguna rendah. Kepuasan pengguna tidak banyak berubah meskipun kinerja atribut ditingkatkan.

3. One-dimensional (O). One-dimensional menggambarkan peningkatan kepuasan pengguna secara proporsional apabila atribut ini ditingkatkan. Sebaliknya, kepuasan akan menurun jika kinerja atribut ini menurun. 4. Indifferent (I). Indifferent merupakan atribut yang dinilai oleh pengguna, ada atau tidak ada, tidak akan berpengaruh terhadap kepuasan pengguna sistem.

5. Reverse (R). Reverse merupakan atribut yang jika kinerjanya tinggi malah akan menurunkan kepuasan pengguna sistem.

6. Questionable (Q). Questionable menunjukkan atribut yang dinilai responden tidak konsisten. Jawaban atau respon dari responden tidak sesuai dengan pernyataan (membingungkan). 
Untuk menentukan kategori dari tiap-tiap atribut, digunakan Blauth Formula sebagai berikut:

a. Jika (one dimensional + attractive + must be) > (indifferent + reverse + questionable) maka grade yang diperoleh dari yang paling maksimum dari (one dimensional, attractive, must be).

b. Jika (one dimensional + attractive + must be) < (indifferent + reverse + questionable) maka grade yang diperoleh dari yang paling maksimum dari (indifferent, reverse, questionable).

Alasan menggunakan Blauth Formula ialah karena pada dasarnya metode Kano terdiri dari tiga kategori yaitu one dimensional, attractive, must be. Akan tetapi dalam respon pengguna selalu ada dan muncul kategori indifferent, reverse, questionable. Penggunaan Blauth Formula ini juga ditujukan untuk memperoleh final grade kategori pada setiap atribut.

Dari hasil yang telah kita peroleh setelah melakukan perhitungan menggunakan Blauth Formula, dapat pula kita hitung koefisien kepuasan dan kekecewaan pengguna menggunakan rumus Better and Worse dengan rumus dapat dilihat pada Persamaan (2.1) berikut:

$$
\begin{aligned}
& \text { Better }=\frac{A+0}{A+0+M+I} \\
& \text { Worse }=-\frac{O+M}{A+O+M+I}
\end{aligned} \quad \text { Persamaan....(2.1) }
$$

a. Menghitung tingkat kepuasan Koefisien (Extent of Satisfication) tingkat kepuasan berkisar antara 0 sampai 1, semakin dekat dengan nilai 1 maka semakin mempengaruhi kepuasan pengguna, sebaliknya jika nilai mendekati angka 0 maka dikatakan tidak begitu mempengaruhi tingkat kepuasan pengguna.

b. Menghitung tingkat kekecewaan (Extent of Dissatisfication) jika nilai semakin mendekati angka -1 maka semakin mempengaruhi kekecewaan pengguna, sebaliknya jika nilai mendekati angka 0 maka dikatakan tidak begitu mempengaruhi tingkat kekecewaan pengguna.

Tanda minus (-) yang disimpan di depan koefisien tingkat kekecewaan pengguna adalah untuk menegaskan pengaruh negatif dari kepuasan pengguna pada kualitas produk tidak terpenuhi. Setelah diketahui tingkat kepuasan dan kekecewaan pengguna dari perhitungan Better and Worse maka dapat dibuat grafik atribut kano menggunakan SPSS.

\section{Populasi dan Sampel}

Tabel 2. Jumlah Populasi

\begin{tabular}{|c|c|c|}
\hline No & Nama & Jumlah \\
\hline 1. & Admin & 1 Orang \\
\hline 2. & Staf atau Pegawai & 7 Orang \\
\hline \multicolumn{2}{|c|}{ Total } & 8 Orang \\
\hline
\end{tabular}

Teknik pengambilan sampel menggunakan purposive sampling yang terdapat di Non-Probability
Sampling. Menurut Sugiyono (2017:85), Purposive sampling adalah teknik penentuan sampel dengan pertimbangan tertentu. Pertimbangan tertentu disini ialah orang tersebut merupakan orang yang paling mengerti tentang objek yang sedang diteliti.

\section{Tahapan Penelitian}

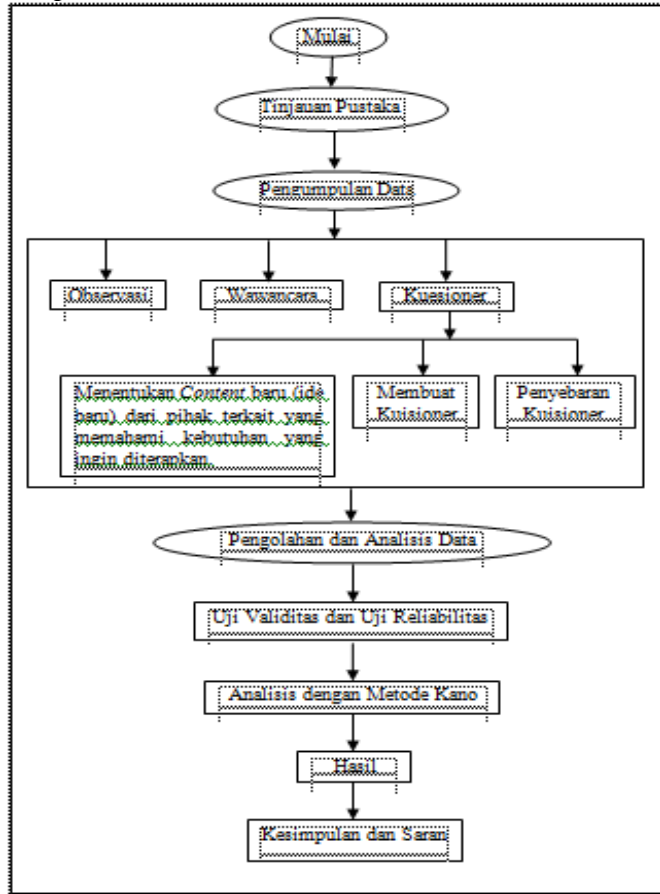

Gambar 1. Tahapan Penelitian

\section{Hasil dan Pembahasan}

A. Pengujian Data

1. Uji Validitas

Instrumen penelitian dikatakan valid jika Koefisien korelasi Product Moment > rtabel (a ; n-2). n = jumlah sampel (Sugiyono, 2017:333). Diketahui : $\mathrm{n}=8, \alpha=$ 0,05 sehingga nilai $r(0,05,8)$ dari tabel Product Moment $=0,811$.

Instrumen penelitian terdiri atas 2 jenis pernyataan yaitu fungsional dan disfungsional. Hasil Analisis uji validitas pernyataan fungsional dapat dilihat pada Tabel 3.2 berikut ini:

Tabel 3. Hasil Analisis Uji Validitas Pernyataan Fungsional

\begin{tabular}{|c|c|c|c|c|}
\hline No & Pernyataan & $\mathbf{r}_{\text {Hitung }}$ & $\mathbf{r}_{\text {Tabel }}$ & Keterangan \\
\hline 1 & Pernyataan 1 & 0,840 & 0,811 & Valid \\
\hline 2 & Pernyataan 3 & 0,869 & 0,811 & Valid \\
\hline 3 & Pernyataan 5 & 0,896 & 0,811 & Valid \\
\hline 4 & Pernyataan 7 & 0,846 & 0,811 & Valid \\
\hline 5 & Pernyataan 9 & 0,856 & 0,811 & Valid \\
\hline
\end{tabular}

(Sumber: Data diolah dengan SPSS versi 22)

Adapun hasil uji validitas pernyataan disfungsional dapat dilihat pada Tabel 3.3 berikut ini: 
Tabel 4. Hasil Analisis Uji Validitas Pernyataan Disfungsional

\begin{tabular}{|c|c|c|c|c|}
\hline No & Pernyataan & $\mathbf{r}_{\text {Hitung }}$ & $\mathbf{r}_{\text {Tabel }}$ & Keterangan \\
\hline 1 & Pernyataan 2 & 0,826 & 0,811 & Valid \\
\hline 2 & Pernyataan 4 & 0,884 & 0,811 & Valid \\
\hline 3 & Pernyataan 6 & 0,881 & 0,811 & Valid \\
\hline 4 & Pernyataan 8 & 0,817 & 0,811 & Valid \\
\hline & Pernyataan & & & \\
5 & 10 & 0,951 & 0,811 & Valid \\
\hline
\end{tabular}

(Sumber: Data diolah dengan SPSS versi 22)

Menurut Tabel $\mathrm{r}$ product moment (Sugiyono, 2017:333) rTabelnya adalah 0,811. Dapat dilihat pada tabel 3 dan tabel 4 setelah dilakukan perhitungan dengan SPSS diperoleh hasil yang valid pada pernyataan yang ada pada instrumen penelitian karena hasil rHitung > 0,811 .

2. Uji Reliabilitas

Uji reliabilitas ini menggunakan model alfa cronbach's karena alternatif jawaban lebih dari 3 pilihan. Pengujian dilakukan dengan menggunakan teknik Cronbach's Alpha. Dapat dilihat pada tabel 5 dan 6 berikut ini untuk uji reliabilitasnya:

Tabel 5. Hasil Analisis Uji Reliabilitas Pernyataan Fungsional

\begin{tabular}{|l|l|l|l|l|}
\hline No & Variabel & Cronbach's Alpha. & N of ltems & Keterangan \\
\hline 1 & Content & 0,902 & 5 & Reliabel \\
\hline
\end{tabular}

(Sumber: Data diolah dengan SPSS versi 22)

Tabel 6. Hasil Analisis Uji Reliabilitas Pernyataan Disfungsional

\begin{tabular}{l|l|l|l|l|}
\hline No & Variabel & Cronbach's Alpha. & N of Items & Keterangan \\
\hline 1 & Content & 0,904 & 5 & Reliabel \\
\hline
\end{tabular}

(Sumber: Data diolah dengan SPSS versi 22)

B. Analisis Metode Kano

1. Perhitungan Dengan Tabel Evaluasi Kano

Hasil rekapitulasi kategori Kano dapat dilihat pada Tabel 4.9 berikut ini:

Tabel 7. Rekapitulasi Hasil Perhitungan Tabel Evaluasi Kano

\begin{tabular}{|c|c|c|c|c|c|c|c|c|}
\hline \multirow[b]{2}{*}{ No } & \multirow[b]{2}{*}{ Atribut } & \multicolumn{6}{|c|}{ Kategori } & \multirow[b]{2}{*}{ Total } \\
\hline & & M & 0 & A & I & $\mathbf{R}$ & $Q$ & \\
\hline 1 & Content Home & 2 & 3 & 2 & 1 & 0 & 0 & 8 \\
\hline 2 & Content Profil & 2 & 1 & 3 & 2 & 0 & 0 & 8 \\
\hline 3 & ContentPendaftaran Online & 3 & 1 & 2 & 2 & 0 & 0 & 8 \\
\hline 4 & Content Galeri Foto & 2 & 3 & 1 & 2 & 0 & 0 & 8 \\
\hline 5 & Content Buku Tamu & 1 & 0 & 4 & 3 & 0 & 0 & 8 \\
\hline
\end{tabular}

Dari Tabel 7 dapat dilihat bahwa kuesioner terdiri atas 5 atribut pernyataan yang disebar kepada 8 orang responden. Berdasarkan metode Kano atribut tersebut dikategorikan ke dalam 6 kategori yaitu, Must Be, One Dimensional, Attractive, Indifferent, Reverse, dan Questionable yang disimbolkan menjadi M, O, A, I, R, dan Q lalu dihitung jumlah masing-masing kategori Kano dalam tiap-tiap atribut sebagai berikut:

a. Atribut Content Home, dari 8 orang responden, ada 2 orang responden yang memilih Must Be, 3 orang responden memilih One Dimensional, 2 orang responden memilih Atrractive, dan 1 orang responden yang memilih Indefferent.

b. Atribut Content Profil, dari 8 orang responden, ada 2 orang responden yang memilih Must Be, 1 orang responden memilih One Dimensional, 3 orang responden memilih Atractive, dan 2 orang responden yang memilih Indefferent.

c. Atribut Content Pendaftaran Online, dari 8 orang responden, ada 3 orang responden yang memilih Must Be, 1 orang responden memilih One Dimensional, 2 orang responden memilih Atrractive, dan 2 orang responden yang memilih Indefferent.

d. Atribut Content Galeri Foto, dari 8 orang responden, ada 2 orang responden yang memilih Must Be, 3 orang responden memilih One Dimensional, 1 orang responden memilih Atractive, dan 2 orang responden yang memilih Indefferent.

e. Atribut Content Buku Tamu, dari 8 orang responden, ada 1 orang responden yang memilih Must Be, 4 orang responden memilih Atractive, dan 3 orang responden yang memilih Indefferent.

2. Perhitungan Dengan Blauth Formula

Berikut hasil rekapitulasi perhitungan menggunakan Blauth Formula dapat dilihat pada Tabel 8 berikut ini:

Tabel 8. Rekapitulasi Hasil Perhitungan Blauth Formula

\begin{tabular}{c|c|c|c|c|c|c|c|c|c}
\hline Atribut & $\mathbf{M}$ & $\mathbf{0}$ & $\mathbf{A}$ & $\mathbf{I}$ & $\mathbf{R}$ & $\mathbf{Q}$ & $\mathbf{0 + A + M}$ & $\mathbf{I + R + Q}$ & Kategori \\
\hline 1 & 2 & 3 & 2 & 1 & 0 & 0 & 7 & 1 & One Dimensional \\
\hline 2 & 2 & 1 & 3 & 2 & 0 & 0 & 6 & 2 & Attractive \\
\hline 3 & 3 & 1 & 2 & 2 & 0 & 0 & 6 & 2 & Must Be \\
\hline 4 & 2 & 3 & 1 & 2 & 0 & 0 & 6 & 2 & One Dimensional \\
\hline 5 & 1 & 0 & 4 & 3 & 0 & 0 & 5 & 3 & Attractive \\
\hline
\end{tabular}

Dari tabel 8 dapat ditarik kesimpulan bahwa atribut 1 yang berisi pernyataan adanya perbaikan content home merupakan kategori One Dimensional, atribut 2 yang berisi pernyataan perbaikan content profil merupakan kategori Attractive, atribut 3 yang berisi pernyataan penambahan content pendaftaran online merupakan kategori Must $\mathrm{Be}$, atribut 4 yang berisi pernyataan perbaikan content galeri foto merupakan kategori One Dimensional dan atribut 5 yang berisi pernyataan penambahan content buku tamu merupakan kategori Attractive.

\section{Perhitungan Better and Worse}

Maka untuk setiap nilai requirement atribut akan menghasilkan nilai Better and Worse seperti rekapitulasi pada tabel 9 dibawah ini: 
Tabel 9. Rekapitulasi Hasil Perhitungan Better And Worse

\begin{tabular}{|c|c|c|c|c|c|c|c|c|c|c|}
\hline Atribut & M & $\mathbf{0}$ & A & I & R & Q & Total & Better & Worse & Kategori \\
\hline 1 & 2 & 3 & 2 & 1 & 0 & 0 & 8 & 0,625 & $-0,625$ & 0 \\
\hline 2 & 2 & 1 & 3 & 2 & 0 & 0 & 8 & 0,50 & $-0,375$ & A \\
\hline 3 & 3 & 1 & 2 & 2 & 0 & 0 & 8 & 0,375 & $-0,50$ & M \\
\hline 4 & 2 & 3 & 1 & 2 & 0 & 0 & 8 & 0,50 & $-0,652$ & 0 \\
\hline 5 & 1 & 0 & 4 & 3 & 0 & 0 & 8 & 0,50 & $-0,125$ & A \\
\hline
\end{tabular}

Dari hasil Better and Worse tiap atribut diatas maka dapat dibuat grafik yang disebut Grafik Atribut Kano, dapat dilihat pada gambar 4.5 berikut:

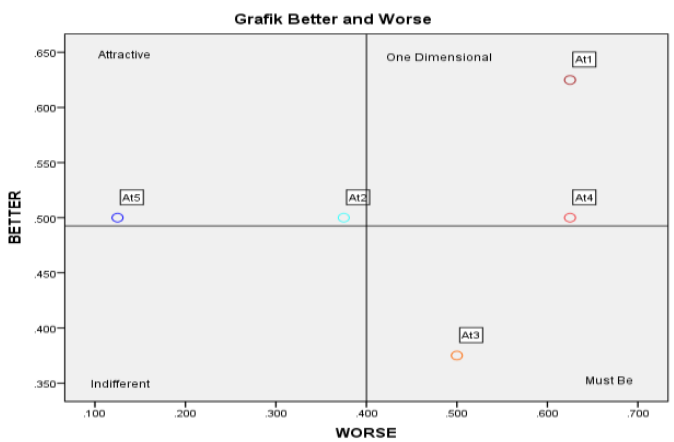

Gambar 2. Grafik Atribut Kano

Pemrosesan dan analisa terhadap rekapitulasi jawaban kuisioner ini menghasilkan kesimpulan bahwa :

a. 1 atribut yang diujikan pada kuisioner berada pada kategori Must Be yaitu pada atribut Content Pendaftaran Online. Must be berarti kepuasan pengguna tidak akan meningkat tinggi walaupun atribut tersebut terpenuhi, namun jika sebaliknya pengguna akan merasa tidak puas. 2 atribut tegolong dalam kategori One-dimensional yaitu pada atribut Content Home dan Content Galeri Foto. Onedimensional berarti tingkat kepuasan pengguna berhubungan linier dengan pemenuhan atribut, sehingga jika atribut tersebut terpenuhi kepuasan pengguna akan meningkat begitu juga jika atribut tersebut tidak terpenuhi maka akan mengakibatkan ketidakpuasan pengguna .

b. 2 atribut tergolong dalam kategori Attractive yaitu pada atribut Content Profil dan Content Buku Tamu yang berarti tingkat kepuasan pengguna akan meningkat jika atribut tersebut terpenuhi, namun penurunan kepuasan tidak akan terjadi walaupun atribut tersebut tidak terpenuhi.

Urutan prioritas penerapan content didasarkan pada kategori yang dimiliki tiap atribut. Urutan kategori yang diprioritaskan yaitu $M>O>A>I$ dan jika terdapat atribut yang berkategori sama, maka yang diprioritaskan terlebih dahulu dapat dilihat dalam grafik dimulai atribut yang ada pada sumbu "worse" jauh dari asal sumbu $\mathrm{x}$ dan pada sumbu "better" dekat asal sumbu y, grafik ini dapat kita ketahui dengan mengukur tingkat kepuasan dan tingkat kekecewaan menggunakan rumus Better and Worse terlebih dahulu.
Berdasarkan Grafik Atribut Kano tersebut dapat dibuat Diagram Atribut Kano (Diagram Kano) seperti gambar 4.6 dibawah ini:

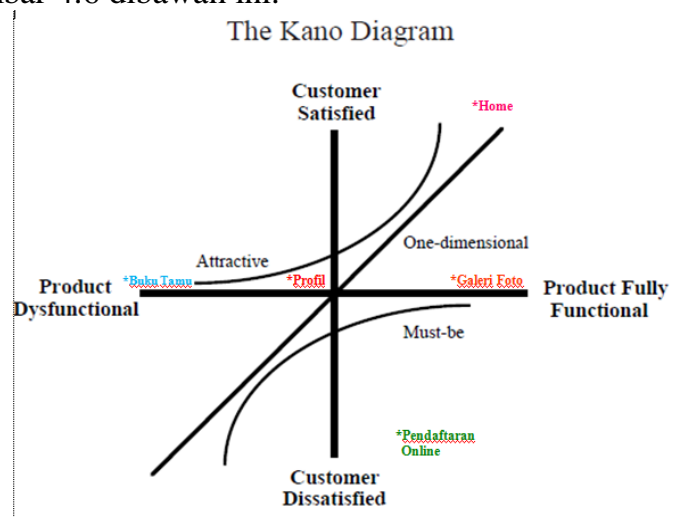

Gambar 3.Diagram Kano

Dari gambar 4.6 bisa diketahui bahwa Content Pendaftaran Online berada pada daerah kategori Must Be, Content Home dan Content Galeri Foto berada pada daerah kategori One Dimensional, dan Content Profil dan Content Buku Tamu berada pada daerah kategori Attractive.

\section{Kesimpulan}

Berdasarkan hasil dari penelitian yang telah dilakukan dapat diambil kesimpulan bahwa:

1. Penambahan Content Pendaftaran Online, yang masuk dalam kategori Must-Be (Harus Ada) yang berarti content ini sudah seharusnya ada pada website. Dengan tingkat kepuasan sebesar 0,375 jika diterapkan dan tingkat kekecewaan -0,50 jika content ini tidak diterapkan.

2. Perbaikan Content Home dan Content Galeri foto, yang masuk dalam kategori One Dimensional yang berarti semakin baik content ini, semakin memuaskan para pengguna dan jika tidak ada content ini maka pengguna akan kecewa. Dengan tingkat kepuasan Content Home sebesar 0.625 jika content ini diterapkan dan tingkat kekecewaan -0,625 jika content ini tidak diterapkan. Sedangkan Content Galeri foto tingkat kepuasannya 0,50 yang berarti lebih kecil dibanding Content Home.

3. Perbaikan Content Profil dan penambahan Content Buku Tamu, yang termasuk dalam kategori Attractive yang berarti pengguna akan merasa senang jika content ini diperbaiki, tetapi tidak akan mengeluh jika tidak ada perubahan. Dengan tingkat kepuasan sebesar 0,50 jika diterapkan dan tingkat kekecewaan $-0,375$ jika content ini tidak diterapkan. Sedangkan Content Buku Tamu memiliki tingkat kepuasan sebesar 0,50 dan tingkat kekecewaan -0,125 yang mana lebih kecil dibandingkan tingkat kekecewaan content Profil.

Urutan prioritas penerapan content didasarkan pada kategori yang dimiliki tiap-tiap atribut. Urutan kategori yang diprioritaskan yaitu $\mathrm{M}>\mathrm{O}>\mathrm{A}>\mathrm{I}$ dan jika terdapat atribut yang berkategori sama, maka yang diprioritaskan 
terlebih dahulu dapat dilihat dalam grafik dimulai dari atribut yang ada pada sumbu "Worse" jauh dari asal sumbu x dan pada sumbu "Better" dekat asal sumbu y, garfik ini dapat diketahui dengan mengukur tingkat kepuasan dan tingkat kekecewaan menggunakan Better and Worse terlebih dahulu.

\section{Daftar Pustaka}

Adhandari, Akyuni. 2018. Analisis Kepuasan Pengguna Dalam Penerapan Sistem Informasi Akademik Menggunakan Metode Kano (Studi Kasus: Universitas Tridinanti Palembang). Palembang: Universitas Islam Negeri Raden Fatah Palembang.

Algifari. 2016. Mengukur Kualitas Layanan dengan Indeks Kepuasan, Metode Importance-Performance Analysis (IPA) dan Model Kano. Yogyakarta: BPFE.

Devani, Vera. Aryo Adi Kuncoro. 2012. Strategi Peningkatan Kualitas Pelayanan Perpusatakaan Uin Suska Riau Dengan Menggunakan Metode Kano. Riau: Jurnal Sains, Teknologi dan Industri. Vol. 10. No. 1.

Feoh, Gerson dan Widagunawan, Putu. 2016. Pengukuran Tingkat Kepuasan Pengguna Situs Web Pemerintah (E-Government) Kabupaten Bandung. Program Studi Teknik Informatika, Sains Dan Teknologi, Universitas Dhyana Pura, Jurnal Teknologi Informasi dan Komputer, Volume 2, Nomor 2, Oktober 2016.

Hutabri, Ellbert. 2015. Penerapan Metode Kano Dalam Analisis Tingkat Kepuasan Mahasiswa Terhadap Penerapan Sistem Informasi Akademik Berbasis Web. Padang: Jurnal Edik Informatika. ISSN: 24070491. Vol VI, 55-63.

Indrayani, Kus. Nofirza. 2011. Aplikasi Metode Kano Dalam Analisis Indikator Pelayanan Rumah Sakit Arifin Ahmad Pekanbaru.Riau: Jurnal Sains, Teknologi dan Industri. Vol. 9. No. 1.

Kano. 1993. Kano's Method for Understanding Customer-defined Quality. Center for Quality of Management Journal, Japan, 2.

Muri Yusuf, A. 2017. Metode Penelitian Kuantitatif, Kualitatif, dan Penelitian Gabungan. Jakarta: KENCANA. ISBN: 978-602-1186-01-5. Vol.4.

Priyatno, Duwi. 2014. SPSS 22: Pengolahan Data Terpraktis. Yogyakarta: C.V ANDI OFFSET.

Putu Agus Eka Pratama, I. 2014. Sistem Informasi dan Implementasinya. Bandung: Informatika Bandung.

Rahmayuni dkk. 2016. Pemanfaatan Metode Kano Untuk Menilai Tingkat Kepuasan Pengguna Terhadap Fungsionalitas Sistem Informasi Kepegawaian (Studi Kasus: AKNP Pelalawan). Padang: Jurnal Inovtek Polbeng. ISSN: 2527-9866. Vol 1, No. 2.

Sahfitri, Vivi. Evi Yulianingsih. 2015. Kualitas Layanan Sistem Informasi Akademik Menggunakan Metode Kano. Palembang: Jurnal Ilmiah MATRIK Vol. 17 No. 2, Agustus 2015: 151-162.
Sugiyono, Dr. Prof. 2017. Metode Penelitian Kuantitatif, Kualitatif, dan $R \& D$. Bandung: Alfabeta.

Wijaya, Dr. Tony. 2018. Manajemen Kualitas Jasa Desain Servqual, QFD, Kano. (Edisi 2). Jakarta: Indeks

Winaya, I Gede, dkk. 2012. Analisis Dan Pemenuhan Kebutuhan Perangkat Lunak Dengan Metode Kano Melalui Pengembangan Berbasis Komponen. Yogyakarta: Semantik 2012. ISBN: 979-26-0255-0.

Yenni, Yusli. 2015. Analisis Kebutuhan Sistem Informasi Pasien Rawat Inap Dengan Menggunakan Metode Kano. Batam: Jurnal Edik Informatika. ISSN: 2407-0491 Vol. 3, 38-48.

Yulianingsih, Evi dan Sahfitri, Vivi. 2015.Kualitas Layanan Sistem Informasi Akademik Menggunakan Metode Kano. Palembang: Universitas Bina Darma.

Yulima, Ade. 2018.Analisis Pengembangan Website Yayasan Islam Az-Zahra Palembang Metode Kano. Palembang: Universitas Islam Negeri Raden Fatah Palembang. 